\title{
Effect of Maritime Traffic and Environmental Variability on the Degradation of Coastal Marin€ Communities - Central Mexican Pacific
}

\author{
Marco Agustín Liñán-Cabello* \\ Facultad de Ciencias Marinas, Universidad de Colima, México
}

Submission: March 08, 2019; Published: March 21, 2019

Corresponding author: Marco Agustín Liñán-Cabello, Facultad de Ciencias Marinas, Universidad de Colima, Carretera Manzanillo Barra de Navidad, C.P. 28860 Manzanillo, Colima, México

\begin{abstract}
Maritime traffic has increased dramatically in the world's oceans over the past 20 years, thus increasing the risk of pollution caused by shipping. Evidence of the effects of a bulk freighter stranding associated with the impacts of a tropical cyclone is presented. Chronic effects from chemical species associated with pollution in a port environment are also described with respect to the physiology of Plicopurpura pansa as a potential bioindicator of health in the intertidal zone of the Central Mexican Pacific. The need to implement strict regulation and control measures over the various impacts resulting from port activity is set forth.
\end{abstract}

Keywords: Plicopurpura pansa; Maritime traffic; Neoplasias; Imposex; Monobutyl tin

\section{Introduction}

Marine coastal ecosystems are considered among the most sensitive and most exposed to anthropogenic influence. One of the most important sources of impact is maritime traffic. In many countries, port development has seen excessive growth and may have multiple forms of impact on marine coastal communities. In particular, the Mexican Central Pacific coast presents one of the routes with highest density of maritime traffic, having as axis the Port of Manzanillo, which is the most important port in Mexico and a strategic point of connectivity with Asia, the United States and Latin America [1]. In addition, due to its geographical position, it is exposed to the occurrence of at least 15 tropical cyclones per year [2]. The emission of chemical compounds associated with maritime traffic has become a growing problem in recent years. Surface emissions resulting from incidental operations may interact in different ways with the marine environment, affecting the ability of most marine species to adapt, reproduce and grow; the level of affectation also depends on the quantity and type of substance that is discharged into the marine environment [3].

\section{Evidence of Impact in the Central Mexican Pacific}

In general, the impacts of port traffic on marine ecosystems can be classified into two broad categories: catastrophic or chro nic effects. The first are the result of large-scale disasters that can lead to the total loss of an ecosystem, while chronic effects are those that result from the daily operation of ships, which can cause subtle impacts or discharges, without leaving clear and concrete evidence [4]. We document below a case of these two types of effects that have occurred in the last three years in a port area in the Mexican Central Pacific.

\section{Catastrophic Impact}

During the El Niño-Southern Oscillation (ENSO) 2015-2016, the cyclone with the highest hazard index ever documented in the Mexican Central Pacific (Hurricane Patricia, category 5) was created. Due to this meteorological phenomenon, the 223 meter-long bulk freighter "El Llanitos", flagged to Mexico, ran aground in the rocky intertidal zone of Punta Graham, Colima, Mexico. Two years after the stranding occurred (Figure 1), high concentrations of cadmium were found in surface seawater ( $3.35 \mathrm{mg} / \mathrm{L}$ ), exceeding the permissible limits for the use of coastal waters for navigation in Mexico (0.1 mg/L). Hydrocarbon concentrations were higher in the aft zone than in the bow area. Snail Plicopurpura pansa specimens collected closest to the ship structure presented a prevalence of 4,2 tumorations in the foot, while the shell structure presen- 
ted patterns of degradation, and there was 31\% imposex [5], that this percentage of imposex was greater than $28 \%$, registered by Dominguez-0jeda and collaborators [6], in a port community of Sonora of the Mexican Pacific. These findings are evidence of sig- nificant impacts on the coastal zone and are also evidence of a lack of response from the authorities to remove and recover damages caused by the grounding.

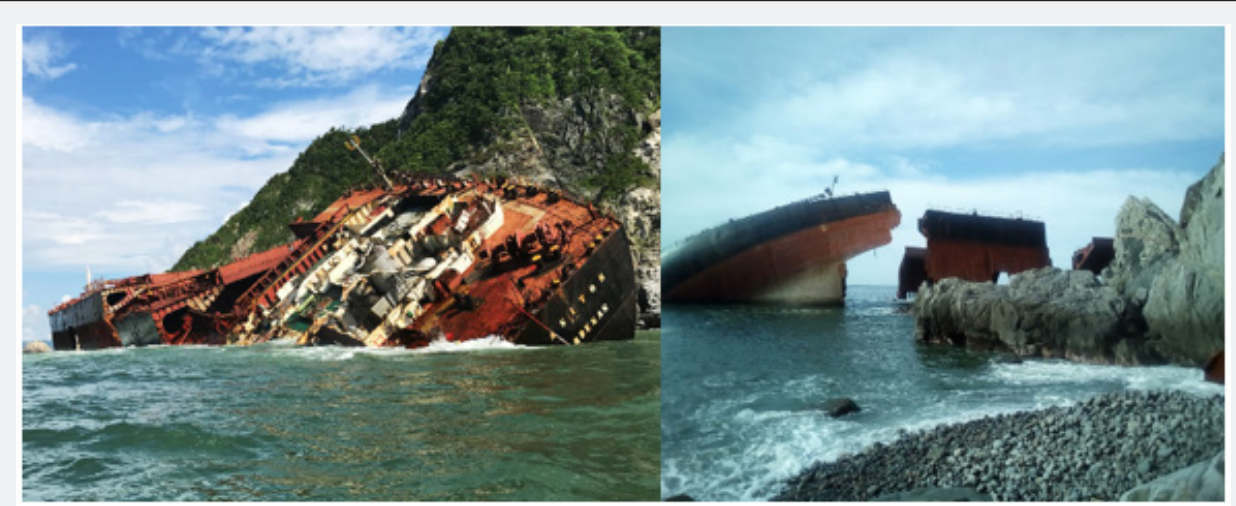

Figure 1: Current status of the "EI LLanitos" which ran aground in the rocky intertidal zone of Punta Graham, Colima, Mexico, as a result of the "Patricia" cyclone that occurred in October 2015.

\section{Chronic Effects}

In a study conducted by Bejarano-Ramírez and collaborators [7], high $\mathrm{Mg}$ and $\mathrm{Pb}$ concentrations were detected inside the harbor, although $\mathrm{Cd}, \mathrm{Cu}, \mathrm{Cr}$, and $\mathrm{Ni}$ concentrations were high inside the Valle de las Garzas Lagoon, which acts as an oxidation pond permanently connected to the inner Manzanillo port. It was also demonstrated that $\mathrm{Cd}$ and $\mathrm{Cr}$ levels increased inside the port during the rainy season, which according to the authors was associated with the cleaning of ships and dock surfaces. The compound As was only present in lagoon sediments during the rainy season. In a later report, low values of biological condition indicators were identified in P. pansa. Histological examinations confirmed the presence of disseminated and gonadal neoplasias linked to areas of greater vessel transit in the port area of Manzanillo. In this study, high concentrations of monobutyl tin (MBT) mainly associated with female tissue were detected [8]. Additionally, there was a decrease in P. pansa abundance compared with the inner port.

It is important to note that although disseminated and gonadal neoplasias have been reported in other parts of the world, this is the first report for Mexico. The chemical analysis of the soft tissue of P. pansa specimens revealed high levels of tin in organic form (monobutyl tin, MBT) that could have originated from organic chemical forms of the metal used as anti-fouling paint (TBT). However, as MBT was not detected by the authors in soft tissues, other alternative sources could be considered. The World Health Organization reports that MBT is associated with the presence of chemical catalyst sand glass coatings and with the manufacture of floors, gloves, PVC prints and other plastic objects [9].

The foregoing exposes only some evidence of the effects of chemical species associated with pollution in a port environment and of the effects on marine life, particularly those that permanently inhabit the rocky intertidal zone. This study also confirms that $P$. pansa can be used as a sensitive bioindicator of environmental health in marine systems. It is necessary to implement strict measures of regulation and control over the various impact agents resulting from the port activity. Short-term actions must be considered to stop the deterioration of biodiversity. Medium- and long-term actions are also required, aimed at restoration, monitoring and protection of coastal environments of greater vulnerability to anthropogenic action and climate change.

\section{References}

1. Wilmsmeier G, Monios J, Pérez-Salas G (2014) Port system evolutionthe case of Latin America and the Caribbean. Journal of Transport Geography 39: 208-221.

2. Connell R, Canevari L, Coleby C, Wright S, Robertson JN, et al. (2015) Port of Manzanillo: Climate Risk Management (Executive Summary).

3. Eyring V, Köhler HW, Van Aardenne J, Lauer A (2005) Emissions from international shipping: 1 . The last 50 years. Journal of Geophysical Research: Atmospheres 110: D17

4. Donaldson JF, Rendle J, McIntyre AD (1994) Safer ships, cleaner seas: report of Lord Donaldson's inquiry into the prevention of pollution from merchant shipping. HMSO.

5. Liñan-Cabello MA \& Castillo I ( 2018) Efectos del encallamiento de un buque granelero durante el Huracán Patricia en la costa de Colima, México. Octavo Congreso Nacional de Investigación en Cambio Climático. Congress held in Colima, México.

6. Domínguez-Ojeda D, Patrón-Soberano, O A Nieto-Navarro, J T de Lourdes Robledo-Marenco, M Velázquez-Fernández J B (2015) Imposex in Plicopurpura pansa (Neogastropoda: Thaididae) in Nayarit and Sinaloa, Mexico. Revista mexicana de biodiversidad 86(2): 531534 .

7. Bejarano-Ramirez I, Jurado JM, Muñiz-Valencia R, Alcázar Á, CeballosMagaña SG, eta al. (2017) Comparative study of $\mathrm{As}, \mathrm{Cd}, \mathrm{Cu}, \mathrm{Cr}, \mathrm{Mg}$, $\mathrm{Mn}, \mathrm{Ni}, \mathrm{Pb}$ and $\mathrm{Zn}$ concentrations between sediment and water from estuary and port. International Journal of Environmental Science and Technology 14(6): 1333-1342.

8. Ahumada-Martínez 0, Hernandez-López J, Liñán-Cabello MA (2018) Occurrence of tumors among gastropods Plicopurpura pansa (Gastrop- 
oda: Neogastropoda) in the Port of Manzanillo, Mexico. Environmental Science and Pollution Research 25(24): 24064-24072.

his work is licensed under Creative

Commons Attribution 4.0 Licens

DOI: 10.19080/OFOAJ.2019.09.555765
9. Dobson S, Howe P, Floyd P (2006) Mono-and disubstituted methyltin, butyltin, and octyltin compounds. In: World Health Organization p. 65

\section{Your next submission with Juniper Publishers will reach you the below assets}

- Quality Editorial service

- Swift Peer Review

- Reprints availability

- E-prints Service

- Manuscript Podcast for convenient understanding

- Global attainment for your research

- Manuscript accessibility in different formats ( Pdf, E-pub, Full Text, Audio)

- Unceasing customer service

Track the below URL for one-step submission https://juniperpublishers.com/online-submission.php 